\title{
Mecklenburg and the Third Rome - the Evocation of Empire
}

\author{
T. Fried
}

For citation: Fried T. Mecklenburg and the Third Rome - the Evocation of Empire. Vestnik of Saint Petersburg University. History, 2020, vol. 65, issue 2, pp. 584-604.

https://doi.org/10.21638/11701/spbu02.2020.215

This article examines the scale of the propaganda for the Russian Empire in Mecklenburg. For many years, the Duchy in the north-east of the Holy Roman Empire had been one of the leading powers in the southern Baltic region. And although the political significance of Mecklenburg steadily faded after the Thirty Years' War, the dukes continued to act on the European stage. In the $18^{\text {th }}$ Century in particular, many and varied contacts arose between the Russian ruling house and that of Mecklenburg. Both the Tsars and the dukes were united in their efforts to prove their rank in the nobility and make themselves known to the outside world. In exploiting their dynastic relationships, very different media were used to present royal power. In this way, a Russian Imperial decoration might become the starting point for other representations of power. The Mecklenburg royal family were particularly concerned with emphasising the imperial rank of their allies. Undoubtedly, this involved associating the empire with Rome and its successors ("translatio imperii"), and references to a "Third Rome" which were also clearly made in Mecklenburg.

Keywords: Mecklenburg, empire, Third Rome, Russia, representation of sovereignty, Order of St. Andrew, medals.

\section{Мекленбург и Третий Рим - вызов империи}

\section{T. Фрид}

Для цитирования: Fried T. Mecklenburg and the Third Rome - the Evocation of Empire // Becтник Санкт-Петербургского университета. История. 2020. Т. 65. Вып. 2. С. 584-604.

https://doi.org/10.21638/11701/spbu02.2020.215

В этой статье рассматривается масштаб пропаганды Российской империи в Мекленбурге. На протяжении многих лет герцогство на северо-востоке Священной Римской империи было одной из ведущих держав в южной части Прибалтики. И хотя политическое значение Мекленбурга неуклонно угасало после Тридцатилетней войны, дуксы продолжали действовать на европейской арене. В частности, в XVIII в. между русским правящим домом и Мекленбургом возникли многочисленные и разнообразные контакты. И цари, и герцоги были едины в попытках укрепить собственное положение среди дворянства и заявить о себе во внешнеполитической сфере. В династических отношениях для представления высшей власти задействовались самые различные области. Так, на эти представления могли повлиять российские имперские награды.

Torsten Fried - Dr. phil. habil., Priv.-Doz., University of Greifswald, Germany; Staatliche Schlösser, Gärten und Kunstsammlungen Mecklenburg-Vorpommern, Münzkabinett, D-19055 Schwerin, Werderstraße 141; torsten.fried@ssgk-mv.de

Торстен Фрид - Dr. phil. habil., приват-доцент, Университет Грайфсвальда; Штаатлише Шлёссер, Гяртен и Кунстсаммлунген Мекленбург-Ворпоммерн, Мюнцкабинет, D-19055 Шверин, Вердерштрассе 141; torsten.fried@ssgk-mv.de

(C) Санкт-Петербургский государственный университет, 2020 
Мекленбургская королевская семья была особенно заинтересована в том, чтобы подчеркнуть императорский ранг своего союзника в лице Российской империи. Несомненно, это было обусловлено ее связью с Римом и его преемниками («translatio imperii»), чем объясняются упоминания «Третьего Рима» в Мекленбурге.

Ключевые слова: Мекленбург, империя, Третий Рим, Россия, представительство суверенитета, орден Святого Андрея, медали.

Our neo-historicist mentality constantly throws up new reasons for historic remembrance - there are anniversaries wherever you look ${ }^{1}$. For instance, in 2018 the media made a great fuss about the fact that the First World War came to an end exactly 100 years earlier. At the same moment that the guns fell silent in November 1918, the monarchy was abolished in Germany; in Mecklenburg too, the Grand Duke Frederick Francis IV (1897-1918) abdicated on 14 November $^{2}$. And so ended the rule of a dynasty that for centuries had shaped the fate of the territory in North-Eastern Germany. Today Mecklenburg no longer exists constitutionally; it has been absorbed into the Federal State of Mecklenburg-Vorpommern ${ }^{3}$. Yet it still remains as part of the name of the federal state. So the future of the land of Mecklenburg - naturally in conjunction with Vorpommern - is no doubt assured even if there are recurring debates about restructuring the Federal Republic of Germany with the prospects of a "Northern state" on the political horizon, into which Mecklenburg (together with Schleswig-Holstein, Hamburg, Lower Saxony and Bremen) would be merged 4 . However, we can hardly expect the land to experience a rebirth elsewhere, so there will be no Second Mecklenburg, but it was different in the case of Rome.

Rome is not just a city: Rome, as it was, embodies an empire which has gone down in history or as the German historian Ferdinand Gregorovius put it, a "Weltwesen" or "holistic world" 5 . Yet for all its power and size, this empire could not last for ever - it fell tragically to the attack of the Barbarians ${ }^{6}$. In the end, Emperor Romulus Augustulus (475-476) was simply deposed by the Ostrogoth King Odoacer (around 476-493). Rome had already been divided into two parts, the Western and the Eastern Roman Empires, since 395. After 476, only one lone Roman Emperor remained who, with his throne in Constantinople, Byzantium, saw his realm as a successor to the Roman Empire. So, the city on the Bosphorus advanced to become the Second Rome ${ }^{7}$. This self-perception still endured when

${ }^{1}$ See the volume: Das historische Jubiläum. Genese, Ordnungsleistung und Inszenierung eines institutionellen Mechanismus Bd. Geschichte. Forschung und Wissenschaft. Münster, 2004.

2 See the volume: Novemberrevolution. Sturz der Monarchie und demokratischer Neubeginn in Mecklenburg 1918-1919. Lübeck, 2019.

3 Schleinert D. Mecklenburg und Vorpommern - Grenzen und Perspektiven einer historischen Annäherung // Mecklenburgische Jahrbücher. 2015. Bd. 130. S. 355.

${ }^{4}$ Nordstaat. Interdisziplinäre Untersuchung zu Chancen und Risiken einer künftigen Zusammenarbeit oder Neugliederung norddeutscher Bundesländer. Nr.80. Kiel, 2006; "Wer braucht den Nordstaat?" Diskussionsbeiträge. Norderstedt, 2010.

${ }^{5}$ On the life and work of Gregorovius, see: Esch A. Ferdinand Gregorovius (1821-1891). Ewiges Rom: Stadtgeschichte als Weltgeschichte // Denker, Forscher und Entdecker. Eine Geschichte der Bayerischen Akademie der Wissenschaften in historischen Porträts. Munich, 2009. S. 149-162.

${ }^{6}$ See in general: Das Ende der Weltreiche. Von den Persern bis zur Sowjetunion. Munich, 1997; Münkler H. Imperien. Die Logik der Weltherrschaft - vom Alten Rom bis zu den Vereinigten Staaten. Berlin, 2005.

7 The Berlin Byzantine expert R. J.Lilie gave his book the simple title: Lilie R. J. Byzanz. Das zweite Rom. Berlin, 2003. 
Charlemagne (768-814) was crowned emperor in $800^{8}$. Yet, just like the First Rome, the Second Rome could not withstand its fate: in 1453, Constantinople, Byzantium, was taken by the Ottomans under Fatih Sultan Mehmet, or Mehmed II, known as "the Conqueror" (1451-1481). And so, the Second Rome came to an end.

However, this "Romeless" state did not last long, and there was soon an endeavour to give rise to a new Rome. Around 1500, writing from his Russian monastery, the Orthodox monk Philotheus (ca. 1456-1542) declared in an epistle to the Grand Prince Vasili III (1505-1533): "The Church of Old Rome fell because of Apollonic heresy. The gates of the Church of the Second Rome, the city of Constantinople, were smashed by Hagar's grandsons with axes and hatchets. Today however the Holy General Apostolic Church of the Third New Rome is that of your rule and your kingdom, which shall burn more brightly than the sun over everything under heaven in the Orthodox faith to the far corners of the world" 9 . In another letter Philotheus urged the Grand Prince to caution: "See and understand, pious Tsar, that all Christian kingdoms were combined into your own kingdom. Two Romes have fallen, the third stands, a fourth there shall not be..."10

Although the idea of Moscow as the Third Rome formulated by Philotheus was never an official state ideology, the aspiration it expressed shaped social development in Russia in many ways. The idea of Rome guaranteed a universal dimension in connection with the title of Tsar, because it conceptualised the Tsar as both a keeper of the orthodox faith and a protective power beyond the boundaries of the kingdom ${ }^{11}$. Ivan IV, often called "the Terrible" (in fact: the Strong, Russian: "grozny") was the first Muscovite ruler to be

8 See also: Ohnsorge W. Ostrom und der Westen. Gesammelte Aufsätze zur Geschichte der byzantinisch-abendländischen Beziehungen und des Kaisertums. Darmstadt, 1983; Byzanz — das "andere" Europa. Berlin, 2002.

9 Malinin V.N. Starets Eleazarova monastyria Filofei i ego poslaniia. Kiev, 1901. Appendix. P. 50; Kovalenskii M. N. Moskovskaia politicheskaia literatura XVI veka. St. Petersburg, 1914. P. 49. - German translation follows: Jähne A. Moskau — das Dritte Rom // Sitzungsberichte der Leibniz-Sozietät. 1997. Bd. 18. S. 101. - This article in particular looks at important ideas on the subject. Literature on the concept of the "Third Rome" is extraordinarily extensive and reflects the variety of academic opinions; here is a selection: Schaeder H. Moskau das Dritte Rom. Studien zur Geschichte der politischen Theorien in der slavischen Welt. Bd. 1: Osteuropäische Studien. Hamburg, 1929; Lettenbauer W. Moskau das Dritte Rom. Zur Geschichte einer politischen Theorie. Munich, 1961; Gol'dberg A. Historische Wirklichkeit und Fälschung der Idee "Moskau — das Dritte Rom” // Jahrbuch für Geschichte der sozialistischen Länder Europas. Bd. 15. 1971. S. 123-141, and reprint in: Rom als Idee. Bd. 656: Wege der Forschung. Darmstadt, 1993. S. 228-256; Kämpfer F. Moskau das Dritte Rom // 1000 Jahre Christliches Russland. Zur Geschichte der russisch-orthodoxen Kirche. Recklinghausen, 1988. S. 45-56; Rim, Konstantinopol', Moskva. Spravitel'no-istoricheskoe issledovanie tsentrov ideologii i kul'tury do XVII v. VI Mezdunarodnyi Seminar istoricheskikh issledovanii “Ot Rima k Tpet’emu Rimu” Moskva, 28-30 maia 1986 g. Moscow, 1997; Sinicyna N. V. Tretii Rim. Istoki i evoliutsiia russkoi srednevekovoi kontseptsii (XV-XVI vv.). Moscow, 1998; Poe M. Moscow, the Third Rome: The Origins and Transformations of a "Pivotal Moment" // Jahrbücher für Geschichte Osteuropas. Neue Folge. 2001. Bd. 49. S. 412-429; Kudriavtsev M. Moskva - Tretii Rim. Istoriko-gradostroitel'noe issledovanie. Moscow, 2008; Hösch E. Die Idee der Translatio Imperii im Moskauer Russland // Europäische Geschichte Online (EGO). URL: http://www.ieg-ego.eu/hoesche-2010-de (accessed 02.03.2020); Kozyrev I. Moskau - das dritte Rom. Eine politische Theorie mit ihren Auswirkungen auf die Identität der Russen und die russische Politik. Göttingen, 2011; Roll Ch. Drittes Rom. Bd. 2: Das Haus Europa. Munich, 2012. S. 291-298.

10 Malinin V.N. Starets Eleazarova monastyria Filofei i ego poslaniia. P.55-56; Kovalenskii M.N. Moskovskaia politicheskaia literatura XVI veka. P. 49.

11 See: Barudio G. Die Macht des Hegemonialismus — das Moskauer Zartum // Pipers Handbuch der politischen Ideen. Bd. 3. Munich; Zurich, 1985. S. 191. 
crowned Tsar; it was not by chance that the coronation was based on Byzantine ritual ${ }^{12}$. Ivan IV claimed sole rule ("samoderžavie") for the Tsars in the Russian empire ${ }^{13}$. And, equally important to his self-image as a ruler, he endeavoured to make the kingdom equal to the Byzantine empire ${ }^{14}$. One visible sign of this was the adoption of the double-headed eagle of the coat of arms of Byzantium (already introduced under Ivan III (1462-1505) by the new tsarist empire ${ }^{15}$. There was another boost to the legitimacy for the Russian rulers when Tsar Peter I (1682-1725) adopted the title of Emperor ("Gossudar Imperator") after the end of the Great Northern War in 1721 (Fig. 1) ${ }^{16}$. With this, Peter wanted to show "that Russia had outgrown Muscovy, was part of Europe, and its ruler intended fully to compete with the Roman Emperor"17. Admittedly, it was not a renewed title of Byzantine emperor but a Russian one that superseded the name of Tsar. And this Russian empire was invoked in Mecklenburg. How did this happen?

12 Sin sviashchennogo venchaniia na Tsarstvo pervovo Russkogo Tsaria Ioanna Vasilevicha IV // Drevne-russkie pamiatniki sviashchennogo venchaniia tsarei na tsarstvo v sviazi s grecheskimi ikh orginalami. Chteniia v Imperatorskom obshchestve istorii i drevnostei rossiiskikh pri moskovskom universitete. Vol. 124. Moscow, 1883. P. 64-66. On the coronation of Ivan see: Miller D. B. The Coronation of Ivan IV of Moscow // Jahrbücher für Geschichte Osteuropas. Neue Folge. 1967. P. Bd. 15. S.559-574, and Nitsche P. Großfürst und Thronfolger. Die Nachfolgepolitik der Moskauer Herrscher bis zum Ende des Rjurikidenhauses. Bd.21: Kölner historische Abhandlungen. Cologne; Vienna, 1972. S. 259-276; see also now: Skrynnikov R. G. Krest i korona. Tserkov' i gosudarstvo na Rusi IX-XVII vv. St. Petersburg, 2000. P.225; Bogatyrev S. Reinventing the Russian Monarchy in the 1550: Ivan the Terrible, the Dynasty, and the Church // The Slavonic and East European Review. 2007. Vol. 85. P.271-293, here P.274, no. 12 in particular.

13 The correspondence exchanged between Ivan IV and Andrey Mikhaylovich, Prince Kurbsky, (1528-1583) from 1564 to 1579 is a unique source of Russia's political history of ideas: Der Briefwechsel Iwans des Schrecklichen mit dem Fürsten Kurbskij (1574-1579). Leipzig, 1921; Der Briefwechsel zwischen Andrej Kurbskij und Ivan dem Schrecklichen. Eine Auswahl mit Einleitung und kurzem Glossar. Wiesbaden, 1961. - See finally: Filiuskin A.I. Andrei Michailovich Kurbskii. Prosopograficheskoe issledovanie i germenevticheskii kommentarii k poslaniiam Andreia Kurbskogo Ivanu Groznomy. St. Petersburg, 2007.

14 Thus formulated by Andreev I. Zeremoniell als Sinnbild der Macht. Die ersten Romanows und ihre kirchlichen und höfischen Zeremonien // Bilder der Macht in Mittelalter und Neuzeit. Byzanz Okzident - Rußland. Göttingen, 2007. S. 520. In this sense e.g. also Skrynnikow R. G. Iwan der Schreckliche und seine Zeit. Munich, 1992. S. 29-31; Jena D. Die russischen Zaren in Lebensbildern. Unter Mitarbeit von R. Lindner. Graz; Cologne; Vienna, 1996. S.32f. - More recently the reference to Byzantium has been questioned, e. g. Hösch E. Die Idee der Translatio Imperii im Moskauer Russland // Europäische Geschichte Online (EGO). URL: http://www.ieg-ego.eu/hoesche-2010-de (accessed 02.03.2020). Kappeler takes an approach that is worthy of consideration, whereby the Muscovite autocracy combined its own east Slavic traditions with Byzantine and Tatar elements: Kappeler A. Russische Geschichte. Munich, 2014. S.21f.

15 Alef's opinion that the Russian double-headed eagle stems from a Habsburg precursor is still disputed; Alef G. The Adoption of the Muscovite Two-Headed Eagle: A Discordant View // Speculum 1966, vol. 41. P. 1-21. See also: Keghel I. de. Imperiales Erbe. Das heutige Russland und sein Staatswappen // Zeithistorische Forschungen/Studies in Contemporary History. Online Edition 2006. Bd. 3, Hft. 1. URL: http:// www.zeithistorische-forschungen.de/1-2006/id $=4549$ (accessed 02.03.2020). Schaeder cited Aleksandr Solov'ev, who, according to her, had already convincingly established in 1935: "The Russian sovereign adopted the double-headed eagle in 1472 probably because he married the daughter of the despot of Mistra. So the double-headed eagle passed into the Russian armoury, first as an emblem of relationship, then as a symbol of Byzantine rule and finally as coat of arms of the Russian empire". Schaeder H. Das neue Israel Gottes: Neues und Drittes Rom. Einhorn und Doppeladler // Russland - Deutschland - Amerika, Russia - Germany - America. Festschrift für Fritz T. Epstein zum 80. Geburtstag. Wiesbaden, 1978. S. 10 (there also the quotation).

${ }^{16}$ On the complex origins of the Russian title of emperor see: Madariaga I. de. Tsar into Emperor: the title of Peter the Great // Royal and republican sovereignty in early modern Europe. Essays in memory of Ragnhild Hatton. Cambridge, 1997. P.351-381. - Also always worth a look: Wittram R. Peter I. Czar und Kaiser. Zur Geschichte Peters des Großen in seiner Zeit. 2 vol. Göttingen, 1964. Bd. 2. S. 462-474.

17 Duchhardt H., Schnettger M. Barock und Aufklärung.5. Auflage. Munich, 2015. S. 95. 


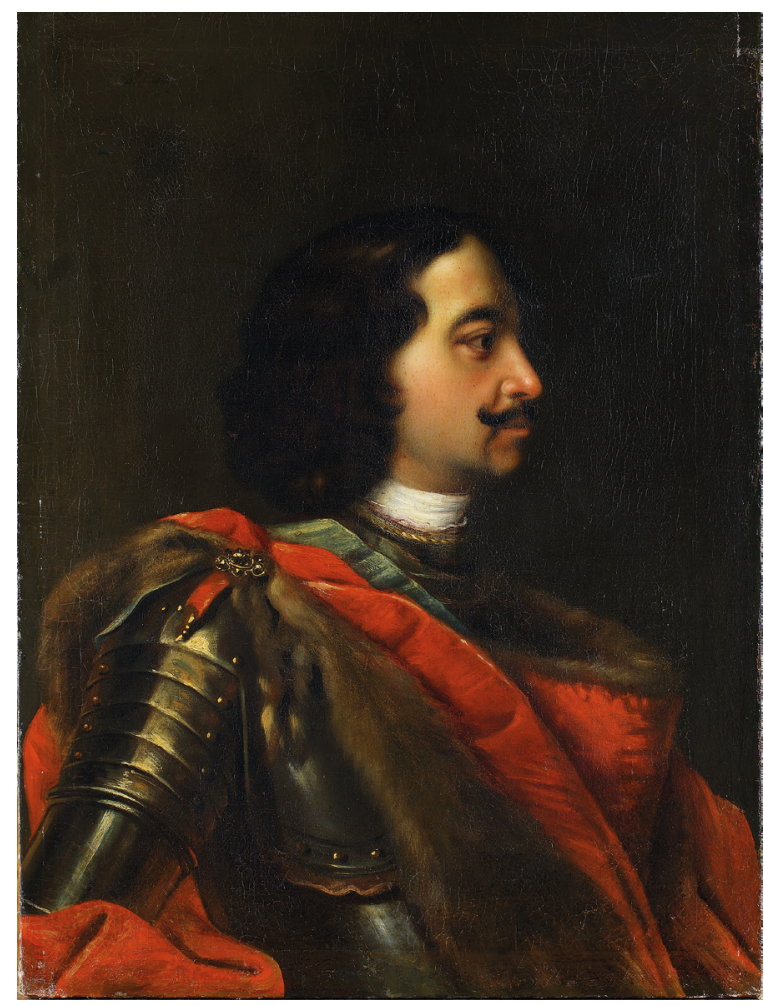

Fig. 1. Johann Kupetzky, Tsar Peter I of Russia, oil on canvas, $85 \times 62 \mathrm{~cm}$ [Staatliche Schlösser, Gärten und Kunstsammlungen Mecklenburg-Vorpommern, Schwerin]

The relationships between Mecklenburg and Russia culminated in Duke Charles Leopold of Mecklenburg-Schwerin (1713-1747) marrying Catherine Ivanovna (1692-1733), niece of Tsar Peter I (1672-1725), in April $1716^{18}$. As part of the celebrations for this event, the Duke of Mecklenburg was admitted to the Russian Order of St. Andrew (Fig. 2) ${ }^{19}$.

18 See: Graff W. P. Die zweite Ehe des Herzogs Karl Leopold. Ein Kulturbild aus Mecklenburg im ersten Viertel des 18. Jahrhunderts // Mecklenburgische Jahrbücher 1895. Bd.60. S. 199-308; Lindemann M. Die Heiraten der Romanows und der deutschen Fürstenhäuser im 18. und 19. Jahrhundert und ihre Bedeutung in der Bündnispolitik der Ostmächte (Bd. 2: Das Reich und Mitteleuropa). Berlin, 1935. S.22f.; Grigorian V. G. Die Romanows und die Mecklenburger Fürsten. Verwandtschaftliche Verflechtungen und Schicksale. Schwerin, 2007. S.10-45; Stellner F. Die dynastische Politik in den russisch-deutschen Beziehungen im 18. Jahrhundert // Deutsch-russische Beziehungen. Politische, wirtschaftliche und kulturelle Aspekte von der frühen Neuzeit bis zum 20. Jahrhundert. Beiträge der internationalen Konferenz in Prag vom 24.-25. November 2005. Prague, 2007. S. 47; Roll Ch. Dynastie und dynastische Politik im Zarenreich // Jahrbuch für Europäische Geschichte. 2007. Bd. 8. S. 86-89; Scharf C. Die Europäisierung Russlands: Bündnisse, Diplomatie, Kriege - die Heiratspolitik der Romanows im 18. und 19. Jahrhundert // Im Glanz der Zaren. Die Romanows, Württemberg und Europa: Katalog der gleichnamigen Ausstellung vom 5. Oktober 2013 bis 23. März $2014 \mathrm{im} \mathrm{Landesmuseum} \mathrm{Württemberg} \mathrm{State} \mathrm{Museum.} \mathrm{Ulm,} \mathrm{2013.} \mathrm{S.} 38$.

19 On the Order of St Andrew see: Spasskii I. G. Inostrannye i russkie Ordena do 1917 goda. Moscow, 2009. P. 163-166; Durov V.A. Russkie Nagrady XVIII - nachala XX v. Moscow, 2003. P. 15-20; Scharf C. Ordena Rossiiskoi imperii. Moscow, 2002. P. 11-27; Shepelëv L. E.: 1) Chinovnyi mir Rossii. XVIII - nachala XX v. St. Petersburg, 1999. P. 327-356; 2) Nagrazhdeniia ordenom Andreia Pervozvannogo za Poltavskuiu pobedu // Numizmatika. 2009. Vol.21. P. 45-47. 


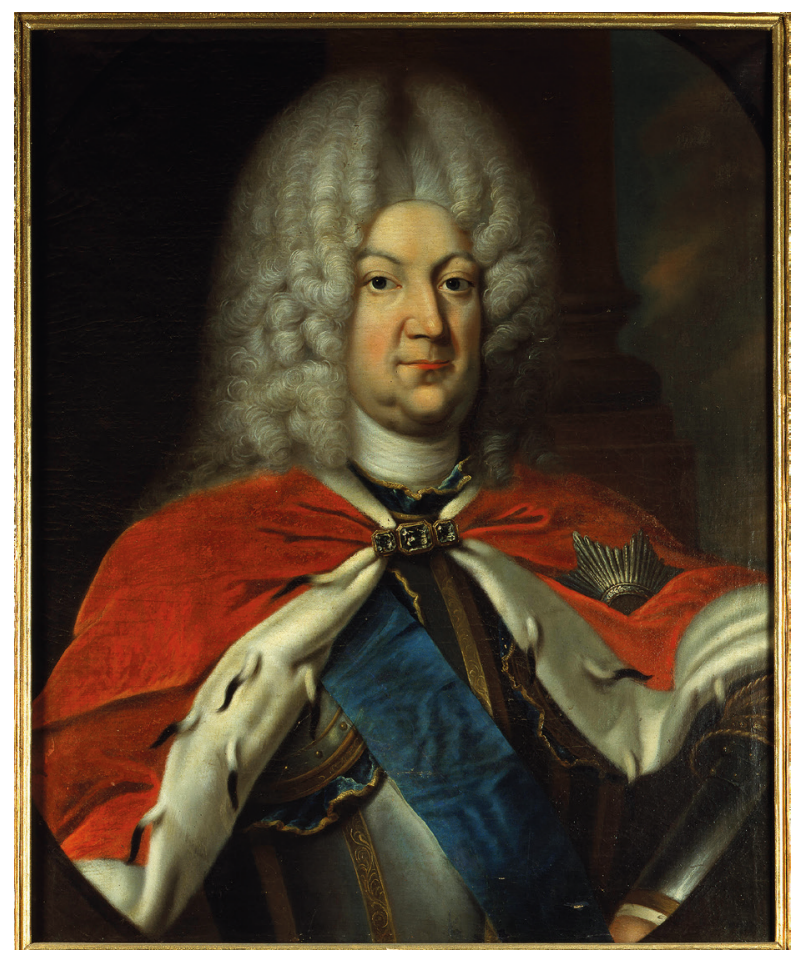

Fig. 2. German, Duke Charles Leopold of Mecklenburg, around 1740, oil on canvas, $76 \times 62 \mathrm{~cm}$ [Staatliche Schlösser, Gärten und Kunstsammlungen Mecklenburg-Vorpommern, Schwerin]

And although Catherine Ivanovna returned home as early as 1722, her abandoned husband retained membership of this order until his death. A not uncommon practice then occurred, i.e., when his successor requested to assume the decoration of his predecessor. On 8 November 1749 the Mecklenburgische Nachrichten read as follows, "Mittwoche, Vormittags, ist der Herzogl. Ober-Jägermeister, Herr von Bergholz, aus Moscau, dahin er von Ihro Herzogl. Durchl. um den von dem höchstseeligen Hertzoge, Carl Leopold, hinterlassenen Orden vom St. Andreas, an Ihro Russisch-Kayserl. Majest. wieder abzugeben, verschickt war, hier zurück gekommen, und hat im Nahmen der Kayserin eben den Orden, welcher in einer besondern Audienz ihm für Ihro Herzogl. Durchl. zurück gegeben, Höchst-Denenselben überreichet". ["Wednesday morning, the Duke's head huntsman, Herr von Bergholz returned from Moscow, whence he was sent by His Serene Highness in order to return the Order of St. Andrew left by the late Duke, Carl Leopold, to Her Imperial Russian Majesty, and did on behalf of the Empress personally present that Order, which was given to him in a special audience for His Serene Highness"] ${ }^{20}$. "His Serene Highness" refers to Duke Christian Louis II of Mecklenburg-Schwerin (1747-1756) ${ }^{21}$.

${ }^{20}$ Mecklenburgische Nachrichten, Fragen und Anzeigungen vom 8. November 1749 // Landeshauptarchiv Schwerin (LHAS). Bd. 1.1-9 Ordensverleihungen, Nr. 23-25.

${ }^{21}$ In general on Christian Louis II, see: Joost S. Christian Ludwig II., Herzog von MecklenburgSchwerin // Biographisches Lexikon für Mecklenburg. Schwerin, 2016. S. 75-79. 
One week later the new membership of the Order was again mentioned in reports: "So haben jetzthochgedachte Ihro Durchl. solchen (das heißt den Orden. - T.F.) den 11ten hujus zum erstenmahl auf eine ganz solenne Art angeleget. Mittags empfingen Ihro Herzogl. Durchl. hierüber die unterthänigsten Gratulations von denen sämtlichen Cavaliers und Dames, auch übrigen Personen von Distinction, und nach gehaltener Tafel wurde Abends gegen 5 Uhr der Bal en Masque eröfnet, und bis gegen 9 Uhr getanzet; Worauf man sich wieder in gemachter bunter Reihe zur Tafel setzte, und ein sehr köstlich angerichtetes Soupé einnahm, dabey die Gesundheiten Ihro Russisch Kayserl. Majest. wie auch des Groß-Fürsten und der Groß-Fürstin, Kayserl. Kayserl. Hoheit, Hoheit unter Pauken- und Trompeten-Schall auch Abfeuerung der Canonen getrunken wurden. Nach aufgehobener Tafel wurde der Bal en Masque wieder bis Morgens um 4 Uhr continuiret, und solchergestalt dieses Festin mit allgemeinem Vergnügen beschlossen [Thus on the $11^{\text {th }}$ His Serene [Highness] celebrated the investment of such [the Order] for the first time in a very solemn way. At noon His Serene Highness received the congratulations of all knights and ladies, as well as other persons of distinction, and after dining the masked ball was opened towards 5 o'clock in the evening, and there was dancing until about 9 o'clock. Whereupon they once again returned to the table in colourful array and had a most delicious supper, whereby the health of Her Imperial Russian Majesty, and those of Their Royal Highnesses, the Grand Duke and Grand Duchess, were drunk to the sound of timpani and trumpets and cannon fire. Afterwards, the masked ball was continued until 4 o'clock in the morning, and this feast was concluded with general enjoyment]"22.

Membership of the imperial Order of St. Andrew became an essential part of the representation of power by the Duke of Mecklenburg Christian Louis II. From now on, there were lavish celebrations of the Order each year; the final time in 1755 - the Duke died half a year later — with a table decorated appropriately for the event: "Auf der Herzogl. Tafel, die überhaupt sehr kostbar serviret, waren besonders die von dem hiesigen Hofconditor, Hr. Hering, bey den Confect Aufsätzen angebrachte Zierathen sehr kunstreich und beträchtlich. In der Mitte der Tafel präsentierte sich ein auf Stuffen erhöheter Baldachin, auf 7 Säulen, in dessen Mitte die hohe Ordenskette, und der Stern auf einem sammettenem Küssen ruhete. Vorne beym Eingange, zur Rechten, stand die Göttin der Künste, Minerva, auf Ihro Rußisch-Kayserl. Majestät deutend, und an deren Postament diese Worte [The Ducal table was adorned sumptuosly, with the decorations created by the court confectioner, Mr. Hering, in particular, whose confectionery displays were very ornate and handsome. In the centre of the table, there stood a tiered baldachin on 7 columns, in the middle of which there was a collar of the high Order, and the star on a velvet cushion. In front of the entrance, on the right, there stood the statue of the goddess of art, Minerva, pointing to Her Imperial Russian Majesty, with these words on the pedestal]:

Vivat Elisabetha!

Russorum Augusta,

Orbis

Delitium, ornamentum.

${ }^{22}$ Mecklenburgische Nachrichten, Fragen und Anzeigungen vom 15. November 1749. 
Zur Linken aber Mars, und an dessen Postament folgende, auf die hohen St. Andreas Ordensritter zielende Beyschrift [Meanwhile on the left there was the statue of Mars with the following inscription referring to the high Order of St. Andrew on his pedestal]:

\author{
Eqvitibus \\ Ordinis Sti. Andreæ \\ dignissimis, \\ vitam, salutem, incolumitatem.
}

Vorwerts presentirten sich in gerader Linie 7 Ehrenbogen, die 7 Hauptprovinzien des Rußischen Kayserthums vorstellende, und zwar ein jeder mit dem Wapen seiner Provinz. Oben aber an dem mittelsten Haupt-Portal, auf einem Pyramidalgebäude die Fama mit einem [At the front there were presented in a straight line 7 triumphal arches, introducing the 7 major provinces of the Russian Empire, each displaying the arms of its province. And on top of the main portal in the middle, on a pyramidal structure the mythical character of Fame with a...]

Vivat!

Hinter diesen befunden sich inwendig 7 Nichen worinnen die besonders jetzo in Rußland florirende freye Künste, unter gewissen Sinnbildern, kunstreich vorgestellet waren. Die übrigen Auszierungen der Tafel bestunden aus 8 verschiedenen Gallerien und Bogenschlüssen, auf deren jedem ein Rußischer Adler, und zu beyden Seiten 2 Genii, mit Palmzweigen und Lorbeerkränzen. An beyden Enden der Herzogl. Tafel stunden noch 2 Ehrnpforten, mit den Ordensbändern und dem Andreas Ordenskreutze, über welchen das Herzogl. Mecklenburgische Wapen und Nahmen, mit Lorbeer und Palmzweigen umgeben, und über denselben eine fliegende Fama [Behind this, within 7 niches the liberal arts that are now flourishing in Russia in particular were ornately presented with certain emblems. The other embellishments of the table comprised 8 different galleries and arches, with a Russian eagle on each, and 2 guardian spirits on both sides, with palm fronds and laurel wreaths. On both ends of the Ducal table there were also 2 triumphal arches, with the ribbons of the Orders and the cross of the Order of St. Andrew, over which the Mecklenburg Ducal arms and names, surrounded by laurel and palm fronds, and over this - a flying figure of Fame]"23.

The emphasis on the Russian empire shows unmistakably what the prince of Mecklenburg associated with membership of this Order. He felt this increased his prestige far more than did any "ordinary" dynastic orders. However, whether he ever formally celebrated the Order of the Elephant is not known. Christian Louis was a member of this royal community from 1737 (No. 231) ${ }^{24}$. Membership of an imperial order did, nevertheless, signify an exceptionally effective distinction from one's peers. So the Prince of Mecklenburg did everything possible to make it visually obvious.

${ }^{23}$ Mecklenburgische Nachrichten, Fragen und Anzeigungen vom 6. December 1755.

${ }^{24}$ LHAS. Bd. 1.1-9 Ordensverleihungen, Nr. 12, 13. See: Berlien J.H.F. Der Elephanten-Orden und seine Ritter, eine historische Abhandlung über die ersten Spuren dieses Ordens und dessen fernere Entwicklung bis zu seiner gegenwärtigen Gestalt, und nächstdem ein Material zur Personalhistorie, nach den Quellen des Königlichen Geheimen-Staatsarchivs und des Königlichen Ordenscapitels-Archivs zu Kopenhagen. Copenhagen, 1846. S. 93f.; Pedersen J. Riddere af Elefantordenen 1559-2009. Odense, 2009. P. 124. 


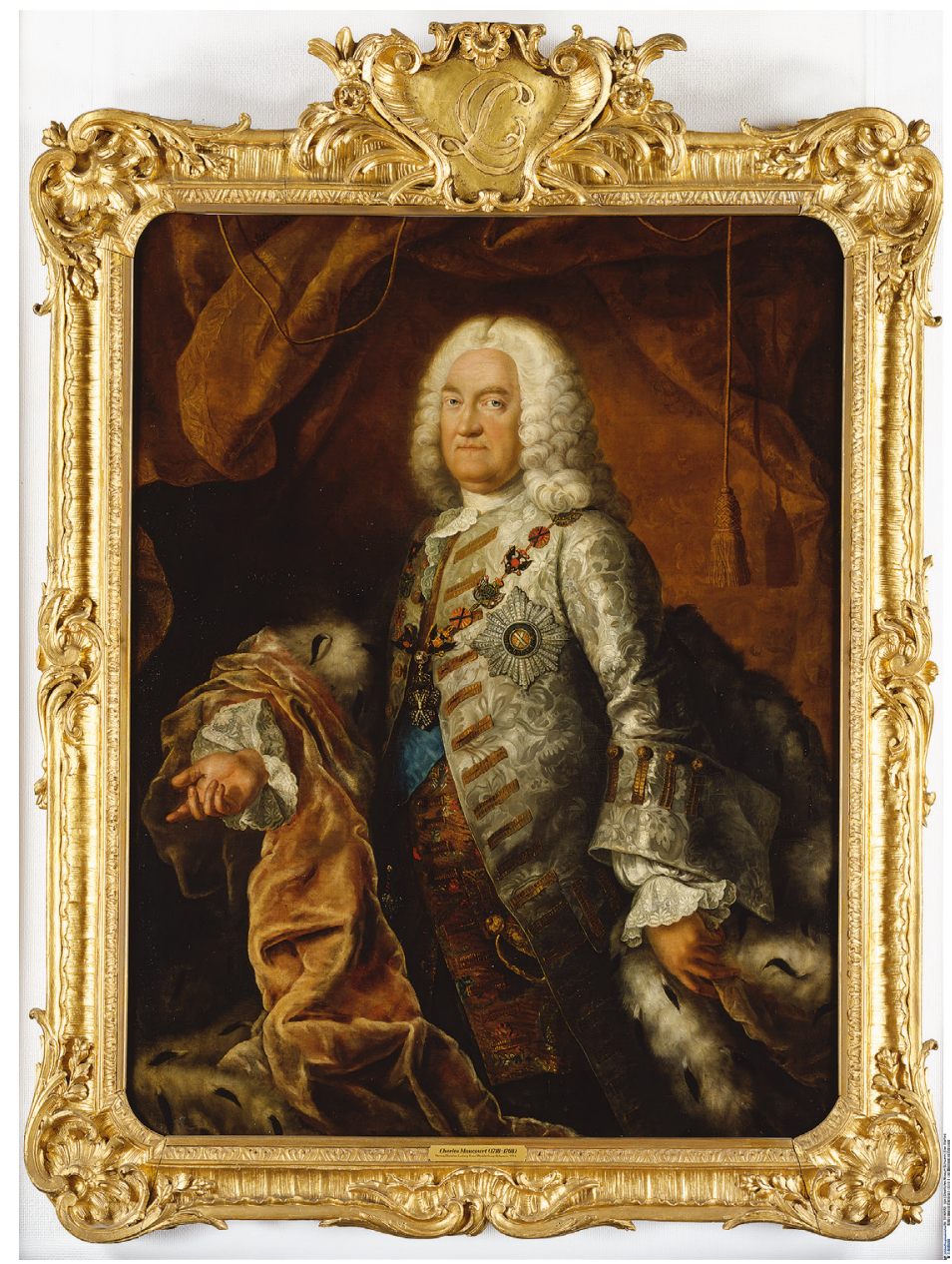

Fig. 3. Charles Maucourt, Duke Christian Louis II of Mecklenburg-Schwerin, 1752, oil on canvas, $142 \times 110 \mathrm{~cm}$ [Staatliche Schlösser, Gärten und Kunstsammlungen Mecklenburg-Vorpommern]

What could be better suited to visualising his new rank than an official portrait? So Christian Louis commissioned it to the French painter Charles Maucourt (1718-1768) who had previously worked at Strelitz. Maucourt painted the duke as if the Order of St. Andrew alone gave him legitimacy and made him a prince (only the blue sash of the Order of the Elephant can be seen, the "Elephant" is barely recognisable) (Fig. 3) ${ }^{25}$. The complete decoration of the Order of St. Andrew consisted of the three elements: a badge, a collar and a star. This delicately painted star signifies it all: it marks the centre of the portrait, and at the same time marks the heart (of the duke) as the seat of the soul and

${ }^{25}$ In summary on the portrait of Christian Louis II see: Baudis H. Christian Ludwig II.von Mecklenburg-Schwerin im Porträt - Zu Aspekten des Herrscherbildes // Mecklenburgische Jahrbücher. 2007. Bd. 122. S.99-119; Hegner K. Fürstliche Repräsentation am mecklenburgischen Hof // Kopie, Replik \& Massenware. Bildung und Propaganda in der bildenden Kunst, Katalog der gleichnamigen Ausstellung im Staatlichen Museum Schwerin vom 12. Oktober 2012 bis 27. Januar 2013. St. Petersberg, 2012. S. 36-40. 

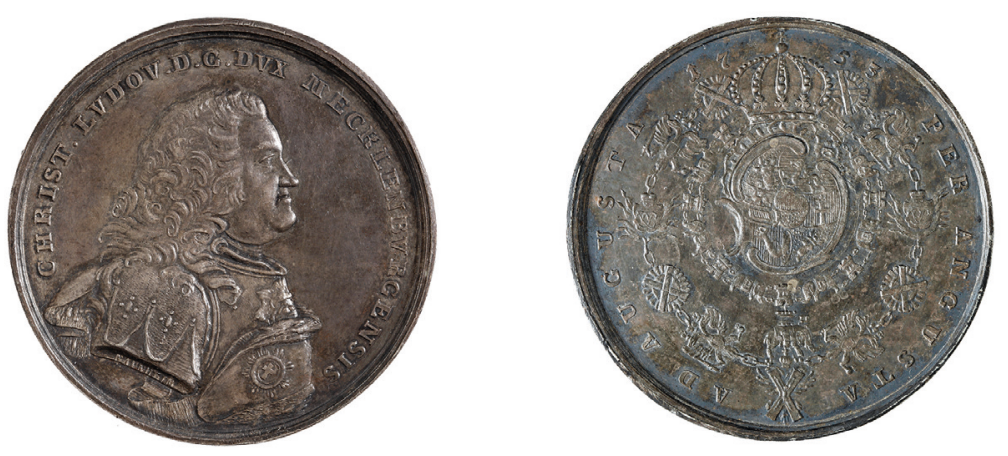

Fig. 4. Duke Christian Louis II of Mecklenburg-Schwerin, medal, 1753, silver, diameter: $46 \mathrm{~mm}$ [Staatliche Schlösser, Gärten und Kunstsammlungen Mecklenburg-Vorpommern, Schwerin]

the conscience ${ }^{26}$. Framing his face with a full-bottomed wig and the collar of the Order ensures a constant shift of focus between the Order and the eyes fixed on us, and emphasises the unity between the individual and the exclusive community; by contrast, all the other elements of the painting are secondary. Nonetheless, regardless of how much the Duke valued the Russian Order, he was not entirely indifferent to the Danish one which is shown in the work of an unknown artist ${ }^{27}$. Strictly speaking, only the blue sash of the Order of the Elephant should be visible beside the Order of St. Andrew in this portrait, however, the painter applied his artistic expertise and reduced the size of the sash, setting the Elephant higher and positioning it closer to the edge of the painting.

There were some teething problems with the medals issued by Christian Louis II (not to mention the coins, as will be seen). The medals first produced after joining the Order (1750) do show both Orders correctly on the reverse, that is, not only the symbol of the Order of the Elephant but also the Order of St. Andrew are grouped around the coat of arms (with the badge of the higher Order being set in the deepest position) (Fig. 4) ${ }^{28}$. However, for reasons of economy, the stamp from the 1749 medal was used on the obverse, and no attention was paid to the fact that the armoured portrait of the duke only bears the Order of the Elephant. This error was only corrected on the pieces issued in 1753 and 1755 respectively when two different Orders were apparent ${ }^{29}$. Certainly, it takes some expertise to spot and identify both stars because the minuteness of the symbols on the medal (which has a diameter of $42-43 \mathrm{~mm}$ ) demands a truly skilled eye. Nevertheless, or perhaps precisely because such details are often deemed unremarkable, this is an especially striking demonstration of how medals depict princely rule.

${ }^{26}$ See: Høystad O.M. Kulturgeschichte des Herzens. Von der Antike bis zur Gegenwart. Cologne; Weimar; Vienna, 2006.

27 Baudis H. Christian Ludwig II.von Mecklenburg-Schwerin im Porträt... S. 107f. (Fig. 6).

${ }_{28}$ Kunzel M. Die Gnadenpfennige und Ereignismedaillen der regierenden Herzöge und Großherzöge von Mecklenburg 1537 bis 1918. Rostock, 1995. S. 80, Nr. 53; Dokumentation der kriegsbedingt vermißten Kunstwerke des Mecklenburgischen Landesmuseums. Bd.2: Münzen, Medaillen, Orden, Ehrenzeichen. Schwerin, 1998. S. 106, Nr. 414.

${ }^{29}$ Kunzel M. Ereignismedaillen. S. 81, Nr. 55-56a; Dokumentation, S. 106, Nr. 416. 

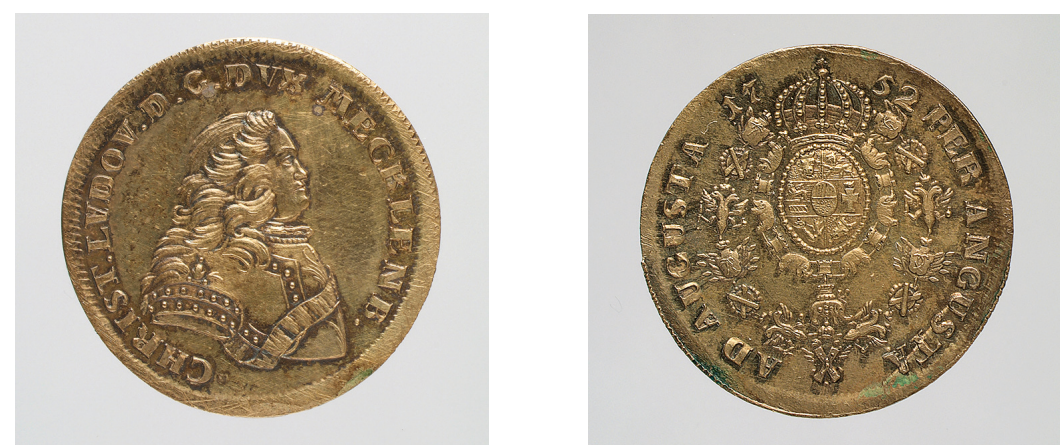

Fig. 5. Duke Christian Louis II of Mecklenburg-Schwerin, 10 ducats, 1752, gold, diameter: $26.7 \mathrm{~mm}$ [Staatliche Schlösser, Gärten und Kunstsammlungen Mecklenburg-Vorpommern, Schwerin]

At first glance, the coins, which in general Christian Louis only had minted since 1752 , look very similar. ${ }^{30}$ On the reverse side, the Orders are depicted "properly" as on the medals. But a careful examination of the portraits on the obverse side reveals only one Order. In the 1752 pieces there is one Order sash; in later issues there is also the star of the Order of the Elephant. According to Carl Friedrich Evers (1729-1803), the 1/4 ducat of 1756 was entirely without any Order symbols; ${ }^{31}$ however, here the founder of Mecklenburg numismatics was wrong because even on this tiny coin (diameter $13.3 \mathrm{~mm}$ ) the aforementioned star is present. On the reverse too, the coat of arms (plus Order) is not shown, only the denomination with the year of minting and motto - in other words, absolutely no reference to the Order of St. Andrew, as early as 1756, seven years after the admission to the Order.

The ducal portrait is not decorated with the Russian Order on any coin; this includes golden 10 and 5 Taler pieces, which were hardly intended for normal circulation as currency (Fig. 5). This is in fact a "contradiction" because the engravers changed in the meantime. While Philipp Aaron (1703-1787) executed the 1749 and 1750 medals, since 1751 Johann Peter Nonheim $(\dagger 1761)$ was the official engraver and die-maker for the duke $\mathrm{e}^{32}$. It is striking that Nonheim did not react to this change and did not design the coins exactly in the same manner as the medals. Even more surprising is the fact that the duke did not intervene and demand that his gold coins were issued with the prestigious

30 Kunzel M. Das Münzwesen Mecklenburgs von 1492 bis 1872. Münzgeschichte und Geprägekatalog (= Berliner Numismatische Forschungen, Neue Folge 2). Berlin, 1994, S.387ff., Nr.308ff. - Five seals of Christian Louis II which show the coat of arms with the Order of the Elephant and the Order of St Andrew are held in the Schwerin State Archive: LHAS. Bd. 11.7-1/5 Fürstenhaus und Zentralbehörden, Herrschaftsund Privatsiegel, Nr. 52-56.

${ }^{31}$ Evers C.F. Mecklenburgische Münz-Verfassung. 2 vol. Schwerin 1798/1799. Leipzig, 1983. Bd. 2. S. 185.

32 See: Virk W. Jüdische Medailleure in Mecklenburg // Mecklenburgische Jahrbücher 1995. Bd. 110. S.97-120. - On Nonheim see: Möller K.A. Elfenbein. Kunstwerke des Barock, Ausstellungs- und Bestandskatalog anlässlich der gleichnamigen Ausstellung vom 31.3.-4.6.2001 im Staatlichen Museum Schwerin. Schwerin, 2000. S. 26-30. - On two relief portraits in stucco by the same artist, missing since the Second World War, the duke was shown wearing both the Danish and Russian Orders: Dokumentation der kriegsbedingt vermißten Kunstwerke des Mecklenburgischen Landesmuseums. Bd. 4: Kunsthandwerk (außer Keramik), Kriegs- und Jagdwesen, Papiergeld, Briefe und Briefmarken. Schwerin, 2005. S. 61, Nr. 173; S. 62, Nr. 177. 


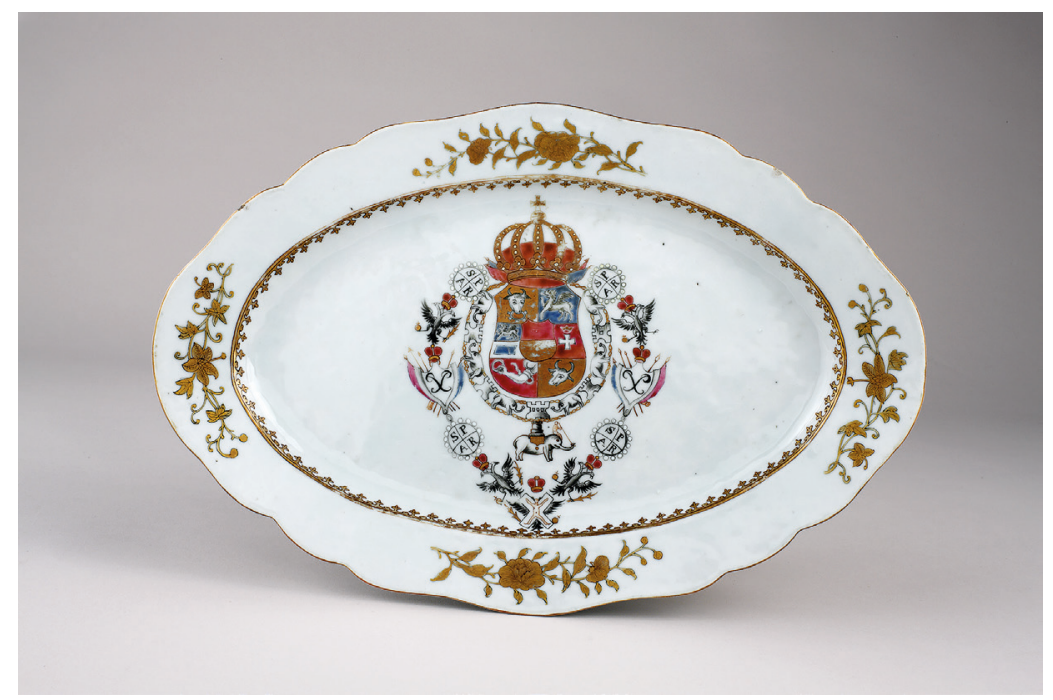

Fig. 6. Oval fruit bowl, 1750-1752, porcelain, China [Staatliche Schlösser, Gärten und Kunstsammlungen Mecklenburg-Vorpommern, Schwerin]

design. On the other hand, Christian Louis attached great importance to the demonstration of the royal Order in another medium of princely representation. For instance, he had two porcelain services produced in China; and all the pieces - fruit bowl, lids, covered tureens, hot dishes, sauce boats or salt cellars - were emblazoned with the Order of St. Andrew alongside the Order of the Elephant. Only forty-nine pieces of the original set of two hundred have survived until today; these are held in the crafts collection of Schwerin Museum (Fig. 6) ${ }^{33}$.

The successor to Duke Christian Louis II, Frederick II, Duke of Mecklenburg-Schwerin (1756-1785), known as "the Pious", was not admitted to the Order of St. Andrew. However, his wife, Louise Frederica (1722-1791) adorned herself with imperial honours from Russia. The court painter Georg David Matthieu (1737-1778) frequently painted the duchess ${ }^{34}$. There are, for example, several variants of her portrait with young black pageboys (Fig. 7$)^{35}$. While the presence of the boy might largely be attributed to the aristocratic fashion for the exotic (which included being shown as a servant proffering a cup of coffee

33 See: Möller K. Chine de Commande. Zwei chinesische Wappenservice für Herzog Christian II. Ludwig von Mecklenburg-Schwerin // Keramos. Zeitschrift der Gesellschaft der Keramikfreunde e. V.Düsseldorf, 1999. Bd. 165. S. 59-68; Fried T. Medaillen verbinden - Herzog Christian Ludwig II. von Mecklenburg-Schwerin und der Gouverneur von Ceylon // Kapitäne, Konsuln, Kolonisten. Beziehungen zwischen Mecklenburg und Übersee. Lübeck, 2015. S. 391-403.

${ }^{34}$ On Louise Frederica see: Merten K. Luise Friederike // Das Haus Württemberg. Ein biographisches. Stuttgart; Berlin; Cologne, 1997. S. 175; Krüger E. Die Musikaliensammlungen des Erbprinzen Friedrich Ludwig von Württemberg-Stuttgart und der Herzogin Luise Friederike von Mecklenburg-Schwerin in der Universitätsbibliothek Rostock. Bd. 1: Studien zur Entstehung und zum Inhalt der Sammlungen. Beeskow, 2006. S. 94-109; in depth Wendt-Sellin U. Herzogin Luise Friederike von Mecklenburg-Schwerin (1722-1791). Ein Leben zwischen Pflicht, Pläsier und Pragmatismus. Bd.: Quellen und Studien aus den Landesarchiven Mecklenburg-Vorpommerns. Cologne; Weimar; Vienna, 2017.

35 Schwibbe I. Georg David Matthieu 1737-1778. Malerei, Pastelle, Grafik. Schwerin, 1978. S.36, Nr. 34-36 (Nr. 34 Fig., S. 49); Hegner K. Fürstliche Repräsentation am mecklenburgischen Hof. S. 42f. 


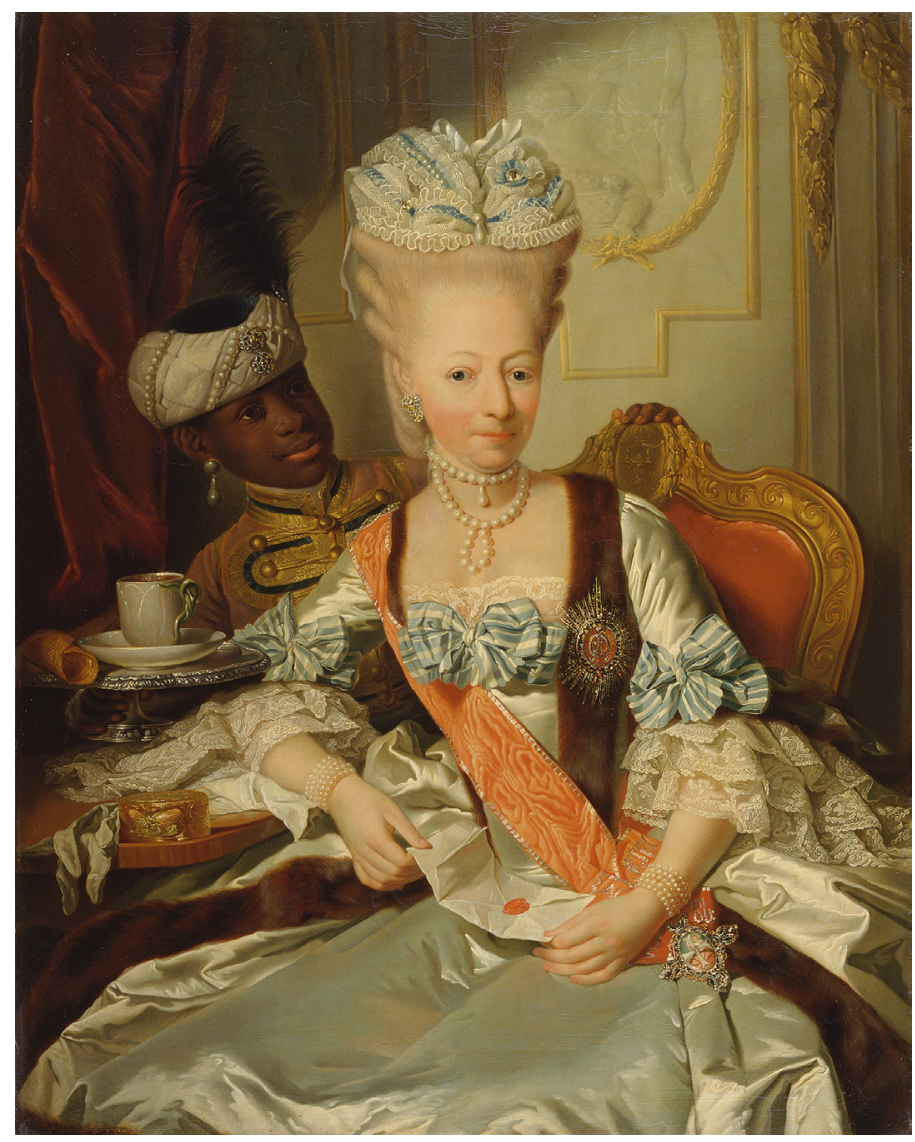

Fig. 7. Georg David Matthieu, Duchess Louise Frederica of Mecklenburg-Schwerin, 1772, oil on canvas, $88 \times 72 \mathrm{~cm}$ [Staatliche Schlösser, Gärten und Kunstsammlungen MecklenburgVorpommern, Schwerin]

to indicate the duchess' liking for the then newly-popular hot drink ${ }^{36}$, the details selected by the painter can be interpreted in several different ways. The extent to which the letter she is holding is supposed to demonstrate her witty and open-minded attitude is not so much of interest here. It is, after all, insignificant in the representation of royal power the Russian Order of Saint Catherine alone is a fitting symbol. Louise Frederica wanted to show the world that she belonged to this imperial community ${ }^{37}$. Other aristocratic ladies from Mecklenburg had been members of the Order before her, for instance, her sister-in-

36 See: Möller K.A. Porzellan aus Fürstenberg. Bestandskatalog. Mit Beitr. von Beatrix Freifrau von Wolff Metternich, Thomas Krueger. Katalog zur gleichnamigen Ausstellung im Staatlichen Museum Schwerin vom 23.2. bis 28.4.2002 und im Museum im Schloss der Porzellanmanufaktur Fürstenberg vom 2.4. bis 29.6.2003. Schwerin, 2002. S. 20. - On black servants at the Court of Mecklenburg-Schwerin see: Möller K.A. Meissener Porzellanplastik des 18. Jahrhunderts. Die Schweriner Sammlung, Katalog der gleichnamigen Ausstellung im Staatlichen Museum Schwerin vom 9. Dezember 2006 bis 11. März 2007. Schwerin, 2006. S. 35f (there also the many articles listed by Karl-Heinz Steinbruch).

${ }^{37}$ LHAS. Bd.1.1-9 Ordensverleihungen. Nr.26; Bd. 2.26-1 Großherzogliches Kabinett I. Nr. 3986. See: Podgornaia N.I. Za liubov' i otechestvo. Orden sviatoi velikomuchenitsy Ekateriny, Part 1: Damy 


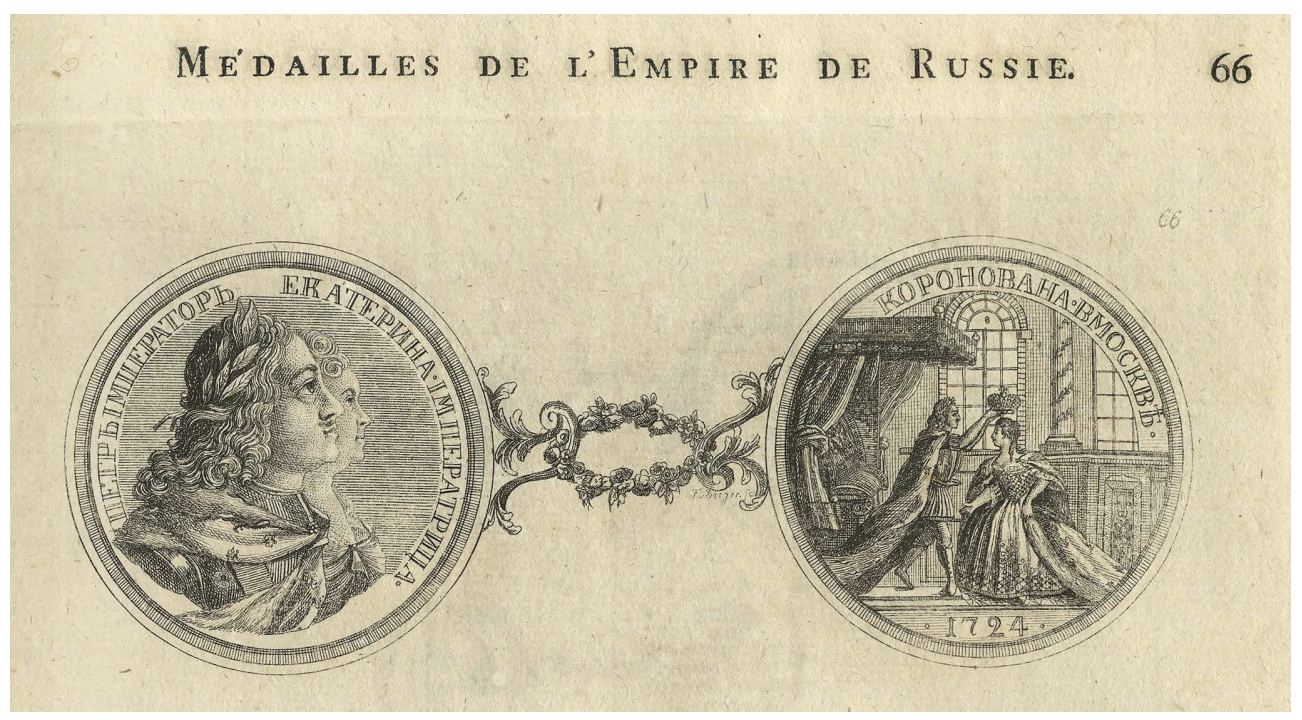

Fig. 8. Tsar Peter I of Russia, medal commemorating the coronation of his second wife, Catherine Alexeyevna, 1724 [Tiregale P. Ricaud de. Médailles sur les principaux événements de l'Empire de Russie depuis le régne de Pierre le Grand jusquà celui de Catherine II. avec des explications histoires. Potsdam, 1772]

law Amalie (1732-1775) ${ }^{38}$. In his paintings, Matthieu leaves nothing to be desired in the representation of the insignia of the Order. The accuracy with which the painter depicts the badge of the Order is truly amazing. The same applies to the ribbon of the Order with the bow, in the folds of which it is even possible to read parts of the motto embroidered in silver in Cyrillic: ЗА ЛЮБОВЬ И ОТЕЧЕСТВО (For Love and Fatherland). Louise Frederica knew what she was doing when she had Matthieu paint her in this way. Who among her peers could display membership of an imperial order of female knights?

In the same year in which Louise Frederica was painted by Georg David Matthieu (1772), a book was published in Potsdam with the title "Médailles sur les principaux événements de l'Empire de Russie depuis le régne de Pierre le Grand jusqu’à celui de Catherine II. avec des explications histoires". This work soon passed from Brandenburg to neighbouring Mecklenburg. As a result, Friedrich von Oertzen (1771-1848), President of the Mecklenburg higher court of appeal, obtained a copy ${ }^{39}$. This later found a place in the Grand-Ducal library in Schwerin ${ }^{40}$. The book depicts a medal closely associated with the Russian empire. Dating from 1724, the piece was minted as a memento of the coronation of the second wife of Peter I, Catherine Alexeyevna (1684-1727) (Fig. 8) ${ }^{41}$. However,

bol'shogo kresta. Riga, 2000. P. 160-161. - See also above the detailed reference work on the Order under No. 19.

38 Podgornaia N. I. Za liubov' i otechestvo. P. 133.

39 Re. Friedrich von Oertzen see: Krause A., Schröder K. „Einem gar wohlgefälligen Bürgersmann zur Ehr...": Ehrenbürgerschaften und Ehrenbürger der Stadt Rostock. Historisches und Biografisches. Rostock, 2010. S. 37-39. - On the Mecklenburg aristocratic family von Oertzen see in general: Buchsteiner I. Die Familie von Oertzen im 19. Jahrhundert // Mecklenburgische Jahrbücher. 2003. Bd. 118. S. 237-254.

40 Landesbibliothek Mecklenburg-Vorpommern Günther Uecker, Signatur: Hf III 300-2 2 .

41 Tiregale P. Ricaud de. Médailles sur les principaux événements de l'Empire de Russie depuis le régne de Pierre le Grand jusquà celui de Catherine II. avec des explications histoires. Potsdam, 1772. P. 66. — The 


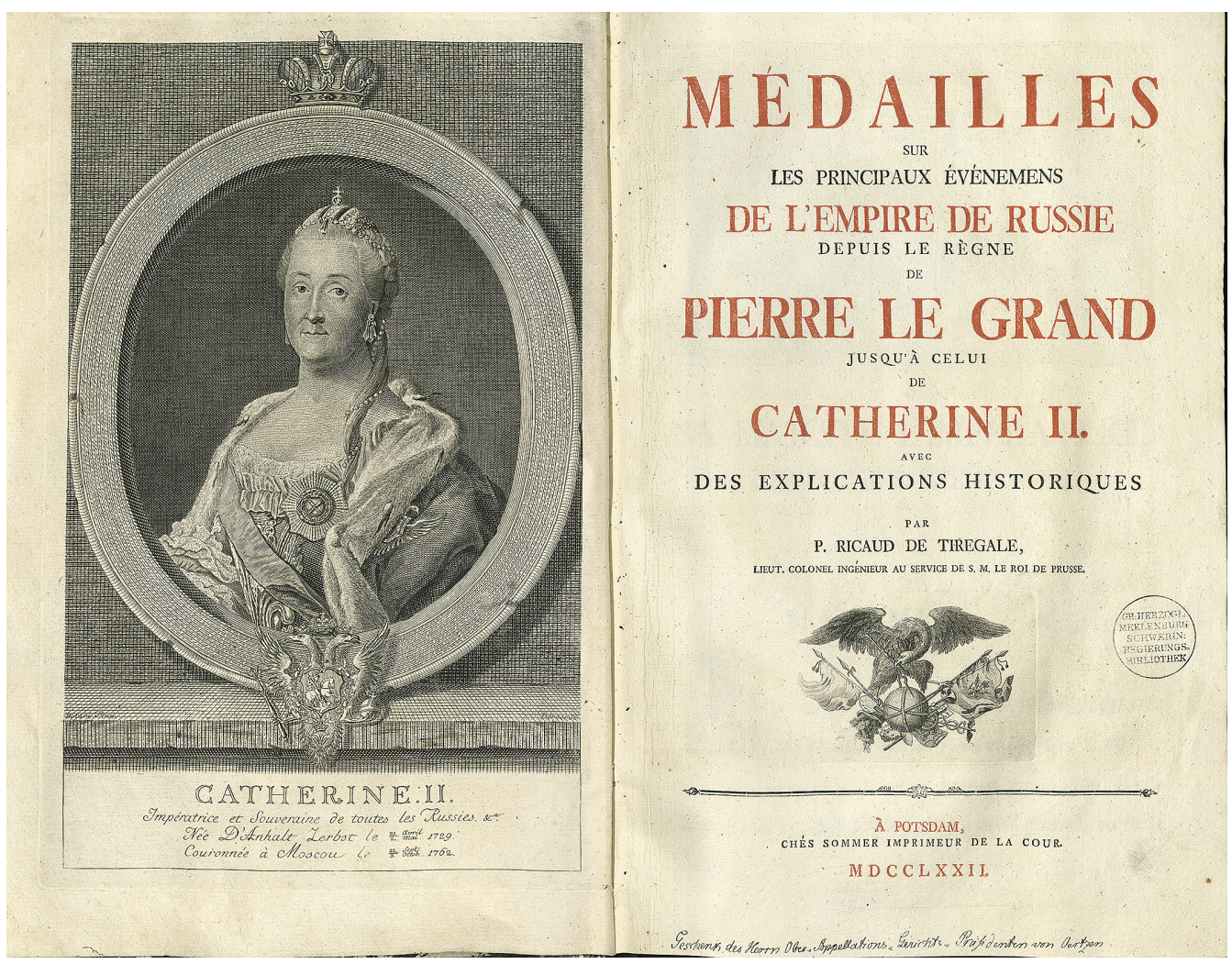

Fig. 9. Pierre Ricaud de Tiregale, Médailles sur les principaux événements de l'Empire de Russie [Tiregale P. Ricaud de. Médailles sur les principaux événements de l'Empire de Russie depuis le régne de Pierre le Grand jusquà celui de Catherine II. avec des explications histoires. Potsdam, 1772]

Peter explicitly did not name her his successor. When he died unexpectedly in 1725 , he left no testament arranging his succession. The former Mecklenburg duchess Catherine Ivanovna herself saw an opportunity of taking the throne in Russia ${ }^{42}$ and becoming Russian Empress - a remarkable scenario. Her ambitious dreams were unfulfilled, and she had to witness the ascent to power of Catherine Alexeyevna - now known as Catherine the Great.

The book of medals published in 1772 was written by Pierre Ricaud de Tiregale (also Tiregaille, Tirregaille) (1721-1776), an official in the service of the Prussian King Frederick II ("the Great") (1740-1786) ${ }^{43}$. The Frenchman was part of an engineering corps, ending up with the rank of a colonel. It is uncertain how Tiregale was so familiar with Russian

1724 medal is recorded in: Diakov M.E. Medals of the Russian Empire. Vol. 1: 1672-1725. Tokyo, 2004. P. 200, no. 60.2. - See collectively also: Walburg R. Zeitzeugen. Münzen aus der Sammlung der Deutschen Bundesbank. Munich, 2018. S. 142-151, in particular S. 146, Nr. 228.

${ }^{42}$ See: Jena D. Die russischen Zaren in Lebensbildern. S. 20f.; Donnert E. Katharina I // Die russischen Zaren 1547-1917. Munich, 2012. S. 179f.

${ }^{43}$ See: Bonin U. von. Geschichte des Ingenieurcorps und der Pioniere in Preußen. 2 Bd. Berlin, 18771878. Bd. 1. S. 113, 299; Allgemeines Lexikon der bildenden Künstler von der Antike bis zur Gegenwart. Bd.28. Leipzig, 1934. S.240; Watroba P. Ricaud de Tirregaille (Tiregale, Tiregalle) Pierre // Słownik architektów i budowniczych środowiska warszawskiego XV-XVIII wieku. Warsaw, 2016. S. 386-389. Ricaud 

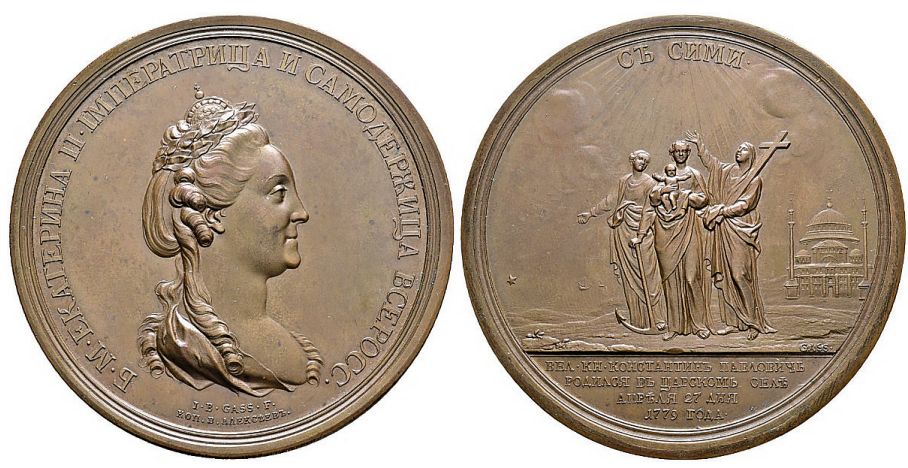

Fig. 10. Tsarina Catherine II of Russia, medal commemorating the birth of her grandson Konstantin, 1779, bronze, diameter: 64.7 mm [Fritz Rudolf Künker GmbH und Co. KG, Osnabrück, auction 251 on $3^{\text {rd }}$ July 2014, Lot No. 3897]

medals that he could compile a "Histoire métallique ${ }^{44}$. Perhaps he had served in Russia before his time in Prussia since his work was dedicated to Tsarina Catherine II (1762-1796) (Fig. 9). Alternatively, it might have been related to the fact that he had worked in Poland since 1752. Russia was a strong presence in the aristocratic republic - without Russian consent no important decisions could be taken ${ }^{45}$. Tiregale acted as an architect and surveyor there. Using precise measurements, in 1762 he presented a map of Warsaw, which was later much copied ${ }^{46}$. In connection with this, he also created detailed drawings of buildings that were extremely helpful in the process of rebuilding the city after the Second World War.

As Tiregale published his work in 1772, it did not include later medals issued by Catherine the Great (Fig. 10). For instance, in 1779 on the occasion of the birth of Grand Prince Konstantin Pavlovich (1779-1831) she had a piece minted with a clear political message (Fig. 11). On the reverse, it shows the Church of Hagia Sophia in Constantinople, promoting the Russian goal of restoring a Byzantine-Greek empire ${ }^{47}$. Or, to put it another

de Tiregale appears in the Prussian lists of ranks and quarters from 1765 (he entered the service on $12^{\text {th }}$ April 1764); Geheimes Staatsarchiv Preußischer Kulturbesitz, I. HA, Rep. 96. Nr. 95. Ll 12. Bd. I.

${ }^{44} \mathrm{He}$ presumably took as his model: Médailles sur les principaux événements du règne de Louis le Grand, avec des explications historiques. Paris, 1702. See on this the volume: Les médailles de Louis XIV et leur livre. Mont-Saint-Aignon, 2015.

45 See: Duchhardt H. Balance of Power und Pentarchie. Internationale Beziehungen 1700-1785. Paderborn et al., 1997. P. 185-188.

46 The map is now reproduced (with Internet sources) in Friedl P. Warschaus Sächsische Achse. Die Planungen August des Starken für seine polnische Residenz im Kontext seiner Unionspolitik // Räume der Macht. Metamorphosen von Stadt und Garten im Europa der Frühen. Bielefeld, 2013. S. 93.

47 Diakov M. E. Medals of the Russian Empire. Vol. 2: 1725-1796. Tokyo, 2005. P. 171-172, no. 177. On the historic background see: Hösch E. Das sogenannte "griechische Projekt" Katharinas II. Ideologie und Wirklichkeit der russischen Orientpolitik in der zweiten Hälfte des 18. Jahrhunderts // Jahrbücher für Geschichte Osteuropas. Neue Folge, 1964. Bd.12. S.336-352; Makrides V. N. Orthodoxie und Politik: Die russisch-griechischen Beziehungen zur Zeit Katharinas II // Katharina II., Russland und Europa. Beiträge zur internationalen Forschung. Mainz, 2001. S. 85-119; Stegnij P. V. [Again on] Das Griechische Projekt Katharinas II // Mitteilungen des Österreichischen Staatsarchivs: 200 Jahre Russisches Außenministerium. 2003. Bd. 50. S. 87-111. - In 1769 Catherine II had a medal cut showing the Hagia Sophia with collapsing minarets; see: Diakov M. E. Medals of the Russian Empire. Vol. 2, no. 146. P. 135-137. 
way: the Third Rome made a claim to the Second Rome with the aid of a medal! Although Catherine's plans were overtaken by reality, her imperial aura was undisputed in Mecklenburg. When the heir to the throne Frederick Francis (from 1785 Duke Frederick Francis I and from 1815 Grand Duke, died in $1837)$ and his wife Louise (1756-1808) stayed in Paris in 1782, they received a bust of the Empress by the renowned sculptor Jean-Antoine Houdon (17411828), depicting her in an inimitable way ${ }^{48}$. The Order of St. Andrew had in any case to be included as evidence of her imperial rank. Naturally, the bust was given place of honour at the Ludwigslust residence of the prince of Mecklenburg-Schwerin ${ }^{49}$.

In conclusion, it is clear that there was propaganda for the Russian empire in Mecklenburg in the $18^{\text {th }}$ Century. The tsars and the dukes united in their efforts to highlight the rank to which they were entitled among royalty. In exploiting their dynastic relationships, very different media were used to present royal power. In this way, a Russian Imperial decoration might become the starting point for other representations of power. Undoubtedly, this associated the empire with Rome and its successors ("translatio imperii"). The concept of a "Third Rome" also clearly had an echo in Mecklenburg.

By autumn 1945, if not earlier, every Mecklenburger must have known about the Third Rome when the German version of Eisenstein's (1898-1948) "Ivan the Terrible" was released. The first screening took place in Schwerin's "Capitol" on 3 October (newspaper "Volkszeitung" dated $3^{\text {rd }}$ October 1945). The dubbing of the Russian film was directed by Wolfgang Staudte (1904-1984), one of the greatest German film directors of the post-war period ${ }^{50}$. In the film, the young tsar passionately recounts - twice - the familiar words: "Two Romes have fallen, But the Third Rome stands. And a fourth there shall not be".

${ }^{48}$ Jean-Baptiste Oudry-Antoine Houdon. Vermächtnis der Aufklärung, Katalog der gleichnamigen Ausstellung im Staatlichen Museum Schwerin vom 26. Mai bis zum 20. August 2000. Schwerin, 2000. S. 170f, Nr.1.

49 The bust can still be seen there today, see: Graulich G. Zwischen Pietismus und Aufklärung. Zur Programmatik der Ludwigsluster Skulpturen im 18. Jahrhundert // Schloss Ludwigslust / hrsg. vom Staatlichen Museum Schwerin; Ludwigslust; Güstrow und den Staatlichen Schlössern und Gärten MecklenburgVorpommern. Munich, 2016. S. 122-124.

50 See: Ludin M. Wolfgang Staudte. Reinbek bei Hamburg, 1996. S.29; Courage und Eigensinn. Zum 100. Geburtstag von Wolfgang Staudte. St. Ingbert, 2006. P. 20; Grün Ch. Chronik: Wolfgang Staudte // Nachdenken über Wolfgang Staudte. Eine Dokumentation zur Veranstaltung im Filmmuseum Potsdam zum 100. Geburtstag. Siegen, 2008. S. 158; Brummel S. Die Werktätigen in DEFA-Spielfilmen: Propaganda in den Filmen der DDR. Hamburg, 2010. S. 15f., Note 96. 


\section{References}

Alef G. The Adoption of the Muscovite Two-Headed Eagle: A Discordant View. Speculum, 1966, vol.41, pp. 1-21.

Andreev I. Zeremoniell als Sinnbild der Macht. Die ersten Romanows und ihre kirchlichen und höfischen Zeremonien. Bilder der Macht in Mittelalter und Neuzeit. Byzanz - Okzident - Rußland. Göttingen, Vandenhoeck \& Ruprecht Publ., 2007, S. 517-538.

Barudio G. Die Macht des Hegemonialismus - das Moskauer Zartum. Pipers Handbuch der politischen Ideen. Bd. 3. Munich; Zurich, Piper Publ., 1985, S. 189-200.

Baudis H. Christian Ludwig II. von Mecklenburg-Schwerin im Porträt - Zu Aspekten des Herrscherbildes. Mecklenburgische Jahrbücher, 2007, Bd. 122, S.99-119.

Berlien J.H.F. Der Elephanten-Orden und seine Ritter, eine historische Abhandlung über die ersten Spuren dieses Ordens und dessen fernere Entwicklung bis zu seiner gegenwärtigen Gestalt, und nächstdem ein Material zur Personalhistorie, nach den Quellen des Königlichen Geheimen-Staatsarchivs und des Königlichen Ordenscapitels-Archivs zu Kopenhagen. Copenhagen, Self-published, 1846, 188 S.

Bogatyrev S. Reinventing the Russian Monarchy in the 1550s: Ivan the Terrible, the Dynasty, and the Church. The Slavonic and East European Review, 2007, vol. 85, pp. 271-293.

Bonin Udo von. Geschichte des Ingenieurkorps und der Pioniere in Preußen. 2 Bd. Berlin, Mittler, 1877-1878, $650 \mathrm{~S}$.

Brummel S. Die Werktätigen in DEFA-Spielfilmen: Propaganda in den Filmen der DDR. Hamburg, DiplomicaVerlag, 2010, $126 \mathrm{~S}$.

Buchsteiner I. Die Familie von Oertzen im 19. Jahrhundert. Mecklenburgische Jahrbücher, 2003, Bd.118, S. 237-254.

Diakov M.E. Medals of the Russian Empire. Vol. 1: 1672-1725. Tokyo, Daruma International Galleries, 2004, $216 \mathrm{p}$.

Diakov M.E. Medals of the Russian Empire. Vol. 2: 1725-1796. Tokyo, Daruma International Galleries, 2005, $256 \mathrm{p}$.

Donnert E. Katharina I. Die russischen Zaren 1547-1917. Hrsg. H.-J. Torke. Munich, Verlag C. H. Beck, 2012, S. 179-184.

Duchhardt H. Balance of Power und Pentarchie. Internationale Beziehungen 1700-1785. Bd. 9: Handbuch der Geschichte der Internationalen Beziehungen. Paderborn u. a, Schöningh Verlag, 1997, 448 S.

Duchhardt H., Schnettger M. Barock und Aufklärung. 5. Auflage. Bd.11: Oldenbourg Grundriss der Geschichte. Munich, Oldenbourg Verlag, 2015, 302 S.

Durov V. A. Orders of the Russian Empire. Moscow, Belyi Gorod Publ., 2002, 223 p. (In Russian)

Durov V. A. Russian Awards of the $18^{\text {th }} I-$ the beginning of the $20^{\text {th }}$ century. Moscow, Prosveshchenie Publ., 2003, 207 p. (In Russian)

Esch A. Ferdinand Gregorovius (1821-1891). Ewiges Rom: Stadtgeschichte als Weltgeschichte. Denker, Forscher und Entdecker. Eine Geschichte der Bayerischen Akademie der Wissenschaften in historischen Porträts. Munich, Verlag C. H. Beck, 2009, S. 149-162.

Evers C. F. Mecklenburgische Münz-Verfassung. 2 Bd. Schwerin 1798-1799. Leipzig, Zentralantiquariat der DDR, 1983, 994 S.

Filjushkin A. I. Andrei Mikhailovich Kurbsky. Prosopographic study and hermeneutic comments on the plans of Andrei Caribbean Ivan the Terrible. St. Petersburg, St. Petersburg University Press, 2007, 620 p. (In Russian)

Fried T. Medaillen verbinden - Herzog Christian Ludwig II. von Mecklenburg-Schwerin und der Gouverneur von Ceylon. Kapitäne, Konsuln, Kolonisten. Beziehungen zwischen Mecklenburg und Übersee. Lübeck, Verlag Schmidt-Römhild, 2015, S.391-403.

Friedl P. Warschaus Sächsische Achse. Die Planungen August des Starken für seine polnische Residenz im Kontext seiner Unionspolitik. Räume der Macht. Metamorphosen von Stadt und Garten im Europa der Frühen Neuzeit. Bd. 13: Mainzer Historische Kulturwissenschaften. Bielefeld, Transcript-Verlag, 2013, S.91-113.

Gol'dberg A. Historische Wirklichkeit und Fälschung der Idee „Moskau - das Dritte Rom“. Jahrbuch für Geschichte der sozialistischen Länder Europas 1971, Bd. 15, S.123-141, and reprint Rom als Idee. Bd. 656: Wege der Forschung. Darmstadt, Wissenschaftliche Buchgesellschaft, 1993, S. 228-256. 
Graff W. P. Die zweite Ehe des Herzogs Karl Leopold. Ein Kulturbild aus Mecklenburg im ersten Viertel des 18. Jahrhunderts. Mecklenburgische Jahrbücher, 1895, Bd.60, S. 199-308.

Grigorian V.G. Die Romanows und die Mecklenburger Fürsten. Verwandtschaftliche Verflechtungen und Schicksale. Schwerin, Demmler Verlag, 2007, 223 S.

Grün Ch. Chronik: Wolfgang Staudte. Nachdenken über Wolfgang Staudte. Eine Dokumentation zur Veranstaltung im Filmmuseum Potsdam zum 100. Geburtstag. Siegen, Böschen Publ., 2008, S. 155-171.

Hegner K. Fürstliche Repräsentation am mecklenburgischen Hof. Kopie, Replik \& Massenware. Bildung und Propaganda in der bildenden Kunst. Katalog der gleichnamigen Ausstellung im Staatlichen Museum Schwerin vom 12. Oktober 2012 bis 27. Januar 2013. Petersberg, Imhof Verlag, 2012, S. 33-51.

Hösch E. Das sogenannte „griechische Projekt“ Katharinas II. Ideologie und Wirklichkeit der russischen Orientpolitik in der zweiten Hälfte des 18. Jahrhunderts. Jahrbücher für Geschichte Osteuropas. Neue Folge, 1964, Bd. 12, S.336-352.

Høystad O.M. Kulturgeschichte des Herzens. Von der Antike bis zur Gegenwart. Cologne; Weimar; Vienna, Böhlau Verlag, 2006, 231 S.

Jähne A. Moskau - das Dritte Rom. Sitzungsberichte der Leibniz-Sozietät, 1997, Bd. 18, S. 97-109.

Jena D. Die russischen Zaren in Lebensbildern. Graz; Cologne; Vienna, Verlag Styria, 1996, 556 S.

Joost S. Christian Ludwig II., Herzog von Mecklenburg-Schwerin. Biographisches Lexikon für Mecklenburg. Schwerin, Verlag Schmidt-Römhild, 2016, S.75-79.

Kämpfer F. Moskau das Dritte Rom. 1000 Jahre Christliches Russland. Zur Geschichte der russisch-orthodoxen Kirche. Recklinghausen, Bongers Verlag, 1988, S. 45-56.

Kappeler A. Russische Geschichte. Munich, Verlag C. H. Beck, 2014, 111 S.

Kovalenskii M.N. Moscow Political Literature of the XVI century. St. Petersburg, Knigoizdatel'stvo TipoLitografii Energiia, 1914, 134 p. (in Russian)

Kozyrev I. Moskau - das dritte Rom. Eine politische Theorie mit ihren Auswirkungen auf die Identität der Russen und die russische Politik. Göttingen, Cuvillier Verlag, 2011, 245 S.

Krause A., Schröder K. „Einem gar wohlgefälligen Bürgersmann zur Ehr...": Ehrenbürgerschaften und Ehrenbürger der Stadt Rostock. Historisches und Biografisches. Rostock, Redieck \& Schade Verlag, 2010, $112 \mathrm{~S}$.

Krüger E. Die Musikaliensammlungen des Erbprinzen Friedrich Ludwig von Württemberg-Stuttgart und der Herzogin Luise Friederike von Mecklenburg-Schwerin in der Universitätsbibliothek Rostock. Bd. 1: Studien zur Entstehung und zum Inhalt der Sammlungen. Beeskow, Ortus Musikverlag, 2006, 334 S.

Kudrjavcev M. P. Moscow - The Third Rome. Historical and Urban Research. Moscow, Troica Publ., 2008, 288 p. (In Russian).

Kunzel M. Das Münzwesen Mecklenburgs von 1492 bis 1872. Münzgeschichte und Geprägekatalog. Berlin, Gebr. Mann Verlag, 1994, 531 S.

Kunzel M. Die Gnadenpfennige und Ereignismedaillen der regierenden Herzöge und Großherzöge von Mecklenburg 1537 bis 1918. Rostock, Verlag Schmidt-Römhild, 1995, 166 S.

Lettenbauer W. Moskau das Dritte Rom. Zur Geschichte einer politischen Theorie. Munich, Verlag Anton Pustet, 1961, 93 S.

Lilie R. J. Byzanz. Das zweite Rom. Berlin, Siedler Verlag, 2003, 576 S.

Lindemann M. Die Heiraten der Romanows und der deutschen Fürstenhäuser im 18. und 19. Jahrhundert und ihre Bedeutung in der Bündnispolitik der Ostmächte. Berlin, Ferd. Dümmlers Verlag, 1935, 176 S.

Ludin M. Wolfgang Staudte. Reinbek bei Hamburg, Rowohlt, Rowohlt-Taschenbuch-Verlag, 1996, 157 S.

Madariaga I. de. Tsar into Emperor: the title of Peter the Great. Royal and republican sovereignty in early modern Europe. Essays in memory of Ragnhild Hatton. Cambridge, Cambridge University Press, 1997, pp.351-381.

Makrides V.N. Orthodoxie und Politik: Die russisch-griechischen Beziehungen zur Zeit Katharinas II. Katharina II., Russland und Europa. Beiträge zur internationalen Forschung. Mainz, Verlag Philipp von Zabern, 2001, S. 85-119.

Malinin V.N. Starets Eleazar monastery Filofei and his mission. Kiev, Tipografiia Kievo-Pecherskoi Uspenskoi Lavry, 1901, 1017 p. (In Russian)

Merten K. Luise Friederike. Das Haus Württemberg. Ein biographisches Lexikon. Stuttgart; Berlin; Cologne, Kohlhammer Verlag, 1997, 175 S.

Miller D. B. The Coronation of Ivan IV of Moscow. Jahrbücher für Geschichte Osteuropas. Neue Folge, 1967, vol. 15, pp. 559-574. 
Möller K. Chine de Commande. Zwei chinesische Wappenservice für Herzog Christian II. Ludwig von Mecklenburg-Schwerin. Keramos. Zeitschrift der Gesellschaft der Keramikfreunde e. V. Düsseldorf, 1999, Bd. 165, S. 59-68.

Möller K.A. Elfenbein. Kunstwerke des Barock. Ausstellungs- und Bestandskatalog anlässlich der gleichnamigen Ausstellung vom 31.3.-4.6.2001 im Staatlichen Museum Schwerin. Schwerin, Staatliches Museum Schwerin, 2000, 310 S.

Möller K. A. Porzellan aus Fürstenberg. With articles by B. Freifrau von Wolff Metternich and Th. Krueger. Katalog zur gleichnamigen Ausstellung im Staatlichen Museum Schwerin vom 23.2. bis 28.4.2002 und im Museum im Schloss der Porzellanmanufaktur Fürstenberg vom 2.4. bis 29.6.2003. [Exhibition catalogue.] Schwerin, Staatliches Museum Schwerin, 2002, 157 S.

Möller K.A. Meissener Porzellanplastik des 18. Jahrhunderts. Die Schweriner Sammlung. Katalog der gleichnamigen Ausstellung im Staatlichen Museum Schwerin vom 9. Dezember 2006 bis 11. März 2007. [Exhibition catalogue.] Schwerin, Staatliches Museum Schwerin, 2006, 268 S.

Münkler H. Imperien. Die Logik der Weltherrschaft - vom Alten Rom bis zu den Vereinigten Staaten. Berlin, Rowohlt Verlag, 2005 (since then various editions), $331 \mathrm{~S}$.

Nitsche P. Großfürst und Thronfolger. Die Nachfolgepolitik der Moskauer Herrscher bis zum Ende des Rjurikidenhauses. Cologne; Vienna, Böhlau Verlag, 1972, 361 S.

Ohnsorge W. Ostrom und der Westen. Gesammelte Aufsätze zur Geschichte der byzantinisch-abendländischen Beziehungen und des Kaisertums. Darmstadt, Wissenschaftliche Buchgesellschaft, 1983, 226 S.

Pedersen J. Riddere af Elefantordenen 1559-2009. Odense, Syddansk Universitetsforlag, 2009, 472 p.

Podgornaia N. I. For love and the fatherland. Order of the Holy Great Martyr Catherine. Tail 1: Ladies of the Cross. Riga, Izdatel' Latviiskii fond social'noi podderzhki molodezhi, 2000, 670 p. (In Russian).

Poe M. Moscow, the Third Rome: The Origins and Transformations of a "Pivotal Moment". Jahrbücher für Geschichte Osteuropas. Neue Folge, 2001, Bd. 49, S.412-429.

Roll Ch. Dynastie und dynastische Politik im Zarenreich. Jahrbuch für Europäische Geschichte 2007, Bd. 8, S. 77-102.

Roll Ch. Drittes Rom Europäische Erinnerungsorte. Hrsg. P. den Boer u. a. Bd. 2: Das Haus Europa. Munich, Oldenbourg Verlag, 2012, S. 291-298.

Schaeder H. Moskau das Dritte Rom. Studien zur Geschichte der politischen Theorien in der slavischen Welt. Hamburg, Friedrichsen, de Guyter Verlag, 1929, 140 S.

Schaeder H. Das neue Israel Gottes: Neues und Drittes Rom. Einhorn und Doppeladler. Russland Deutschland - Amerika, Russia - Germany - America. Festschrift für Fritz T. Epstein zum 80. Geburtstag. Wiesbaden, Steiner Verlag, 1978, S. 1-10.

Scharf C. Die Europäisierung Russlands: Bündnisse, Diplomatie, Kriege - die Heiratspolitik der Romanows im 18. und 19. Jahrhundert Im Glanz der Zaren. Die Romanows, Württemberg und Europa. Katalog der gleichnamigen Ausstellung vom 5. Oktober 2013 bis 23. März 2014 im Landesmuseum Württemberg. [Exhibition catalogue.] Ulm, Süddeutsche Verlagsgesellschaft, 2013, S. 37-45.

Schleinert D. Mecklenburg und Vorpommern - Grenzen und Perspektiven einer historischen Annäherung. Mecklenburgische Jahrbücher 2015, Bd. 130, S. 343-357.

Schwibbe I. Georg David Matthieu 1737-1778. Malerei, Pastelle, Grafik. Schwerin, Staatliches Museum Schwerin, 1978, 63 S.

Shepelev L.E. The official world of Russia. $18^{t}$ - beginning of $20^{\text {th }}$ century. St. Petersburg, Iskusstvo-SPb Publ., 1999, 477 p. (In Russian)

Shepelev L.E. Awarding the Order of St. Andrew the First-Called for the Poltava victory. Numizmatika, 2009, vol.21, pp. 45-47. (In Russian)

Sinitsyna N.V. Third Rome. The origins and evolution of the Russian medieval concept $\left(15^{\text {th }}-16^{\text {th }}\right.$ centuries). Moscow, Indrik Publ., 1998, 410 p. (In Russian)

Skrynnikow R. G. Iwan der Schreckliche und seine Zeit. Mit einem Nachwort von H.-J. Torke. Munich, Verlag C. H. Beck, 1992, 377 S.

Skrynnikov R. G. Cross and crown. Church and state in Russia $11^{\text {th }}-17^{\text {th }}$ centuries. St. Petersburg, Iskusstvo SPb Publ., 2000, 463 p. (In Russian)

Spasskii I. G. Foreign and Russian orders until 1917. Moscow, Veche Publ., 2009, 224 p. (In Russian)

Stegnij P.V. [Yet again about] Das Griechische Projekt Katharinas II. Mitteilungen des Österreichischen Staatsarchivs: 200 Jahre Russisches Außenministerium 2003, Bd. 50, S. 87-111. 
Stellner F. Die dynastische Politik in den russisch-deutschen Beziehungen im 18. Jahrhundert. Deutschrussische Beziehungen. Politische, wirtschaftliche und kulturelle Aspekte von der frühen Neuzeit bis zum 20. Jahrhundert. Beiträge der internationalen Konferenz in Prag vom 24.-25. November 2005. Prague, Verlag Set Out, 2007, S. 31-51.

Tiregale P. Ricaud de. Médailles sur les principaux événements de l'Empire de Russie depuis le régne de Pierre le Grand jusqu'à celui de Catherine II. avec des explications histoires. Potsdam, Sommer Publ., 1772, 111 p.

Virk W. Jüdische Medailleure in Mecklenburg. Mecklenburgische Jahrbücher 1995, Bd. 110, S. 97-120.

Walburg R. Zeitzeugen. Münzen aus der Sammlung der Deutschen Bundesbank. Munich, Hirmer Verlag, 2018, 275 S.

Wątroba P. Ricaud de Tirregaille (Tiregale, Tiregalle) Pierre Słownik architektów i budowniczych środowiska warszawskiego XV-XVIII wieku. Warszawa, Instytut Sztuki PAN, 2016, ss. 386-389.

Wendt-Sellin U. Herzogin Luise Friederike von Mecklenburg-Schwerin (1722-1791). Ein Leben zwischen Pflicht, Pläsier und Pragmatismus. Cologne; Weimar; Vienna, Böhlau Verlag, 2017, 468 S.

Wittram R. Peter I. Czar und Kaiser. Zur Geschichte Peters des Großen in seiner Zeit. 2 Bd., Göttingen, Vandenhoeck \& Ruprecht Verlag, 1964, 1136 S.

Статья поступила в редакцию 12 октября 2019 г.

Рекомендована в печать 12 марта 2020 г.

Received: October 12, 2019

Accepted: March 12, 2020 